
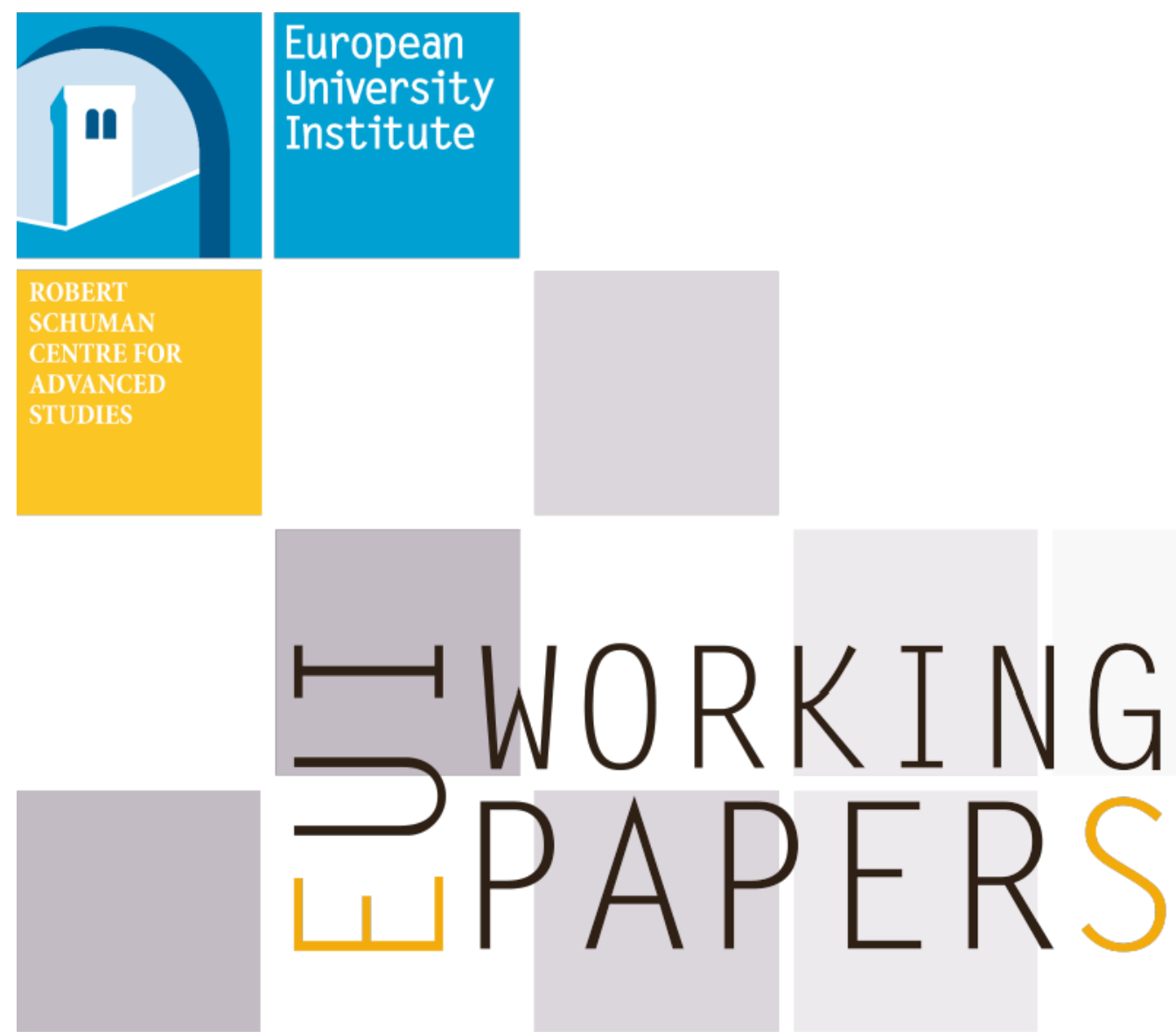

RSC 2021/28

Robert Schuman Centre for Advanced Studies Integrating Diversity in the European Union (InDivEU)

Taking Back Control? Brexit and the Territorial Constitution of the United Kingdom

Michael Keating 

European University Institute

Robert Schuman Centre for Advanced Studies

Integrating Diversity in the European Union (InDivEU)

\section{Taking Back Control?}

Brexit and the Territorial Constitution of the United Kingdom

Michael Keating

EUI Working Paper RSC 2021/28 
Terms of access and reuse for this work are governed by the Creative Commons Attribution 4.0 (CCBY 4.0) International license. If cited or quoted, reference should be made to the full name of the author(s), editor(s), the title, the working paper series and number, the year and the publisher.

ISSN 1028-3625

(C) Michael Keating, 2021

This work is licensed under a Creative Commons Attribution 4.0 (CC-BY 4.0) International license. https://creativecommons.org/licenses/by/4.0/

Published in February 2021 by the European University Institute.

Badia Fiesolana, via dei Roccettini 9

I - 50014 San Domenico di Fiesole (FI)

Italy

Views expressed in this publication reflect the opinion of individual author(s) and not those of the European University Institute.

This publication is available in Open Access in Cadmus, the EUI Research Repository:

https://cadmus.eui.eu 


\section{Robert Schuman Centre for Advanced Studies}

The Robert Schuman Centre for Advanced Studies, created in 1992 and currently directed by Professor Brigid Laffan, aims to develop inter-disciplinary and comparative research on the major issues facing the process of European integration, European societies and Europe's place in $21^{\mathrm{s}}$ century global politics.

The Centre is home to a large post-doctoral programme and hosts major research programmes, projects and data sets, in addition to a range of working groups and ad hoc initiatives. The research agenda is organised around a set of core themes and is continuously evolving, reflecting the changing agenda of European integration, the expanding membership of the European Union, developments in Europe's neighbourhood and the wider world.

For more information: http://eui.eu/rscas

The EUI and the RSC are not responsible for the opinion expressed by the author(s).

\section{European Governance and Politics Programme}

The European Governance and Politics Programme (EGPP) is an international hub of high-quality research and reflection on Europe and the European Union. Launched in 2018, it is part of the research programmes of the Robert Schuman Centre for Advanced Studies at the European University Institute.

The EGPP maintains its core activities through externally funded research projects, including financial support from the European Commission through the European Union budget, and is animated by the Programme Associates, leading scholars from different disciplines brought together by their interest in European integration and its future development.

For more information: http://europeangovernanceandpolitics.eui.eu/

Integrating Diversity in the European Union (InDivEU) is a Horizon 2020 funded research project aimed at contributing concretely to the current debate on the 'Future of Europe' by assessing, developing and testing a range of models and scenarios for different levels of integration among EU member states. InDivEU begins from the assumption that managing heterogeneity and deep diversity is a continuous and growing challenge in the evolution of the EU and the dynamic of European integration.

The objective of InDivEU is to maximize the knowledge of Differentiated Integration (DI) on the basis of a theoretically robust conceptual foundations accompanied by an innovative and integrated analytical framework, and to provide Europe's policy makers with a knowledge hub on DI. InDivEU combines rigorous academic research with the capacity to translate research findings into policy design and advice.

InDivEU comprises a consortium of 14 partner institutions coordinated by the Robert Schuman Centre at the European University Institute, where the project is hosted by the European Governance and Politics Programme (EGPP). The scientific coordinators of InDivEU are Brigid Laffan (Robert Schuman Centre) and Frank Schimmelfennig (ETH Zürich).

For more information: http://indiveu.eui.eu/
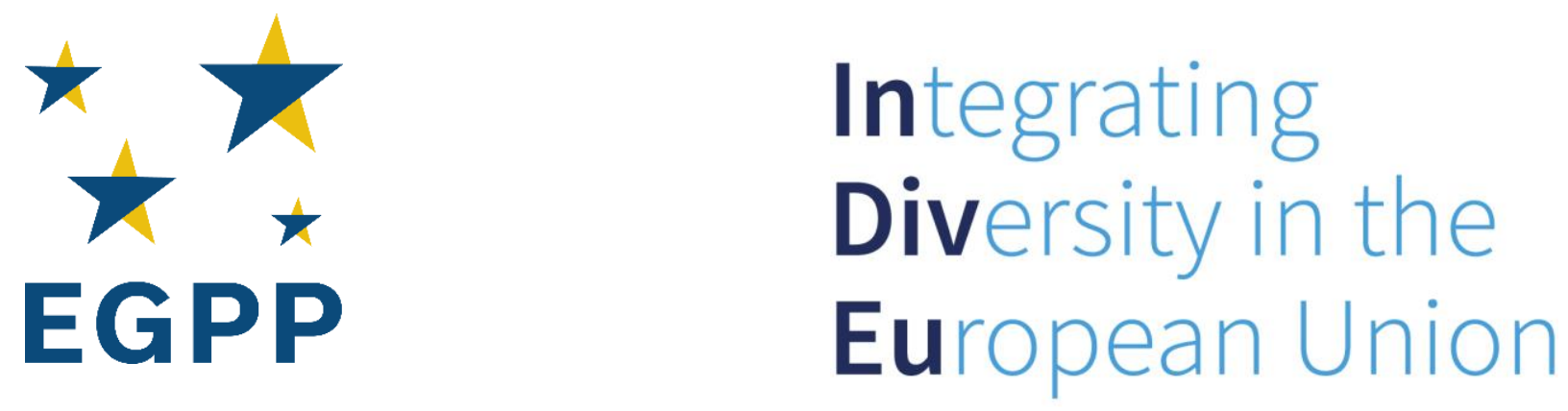

The research leading to this Paper was conducted within the InDivEU project. The project has received funding from the European Union's Horizon 2020 research and innovation programme under grant agreement No. 822304. The funders had no role in the study design, data collection or analysis. 



\begin{abstract}
Brexit aimed to restore sovereignty to the United Kingdom. That rested on an interpretation of the UK as an internally integrated and externally bordered sovereign state. Another interpretation is that the UK is a plurinational union, in which the issue of sovereignty is contested. Devolution in 1999 left this issue in abeyance, while membership of the EU provided an external support system. Brexit removed this external support and resulting territorial tensions are exacerbated by the fact that majorities in Scotland and Northern Ireland opposed it. There have been three responses: to reconstitute the United Kingdom as a unitary state; to fragment it into its constituent parts; and to seek a differentiated Brexit. Only Northern Ireland has been granted such an exception, at the insistence of another member state.
\end{abstract}

\title{
Keywords
}

Brexit; United Kingdom; Scotland; Northern Ireland; Devolution; union 



\section{Two Unions*}

The relationship of the United Kingdom to European integration has long been bedevilled by the question of sovereignty (Grob-Fitzgibbon, 2016). In the absence of a codified constitution, the constitutional orthodoxy is that ultimate authority has rested on of the unbridled sovereignty and supremacy of the Monarch-in-Parliament (Dicey, 1959), This means that the polity is externally bounded, unable to accept any supranational authority and internally unbounded, with no federal-type limits to state scope or authority. Opponents of EU membership consequently argued that it was threat to the basis of the constitution itself. Successive UK governments sought to reconcile the two by arguing that they had merely lent powers to the EU but could take them back at any time. Since 1999, Scotland, Wales and Northern Ireland have had their own legislatures, established after local referendums. Again, according to the Westminster doctrine, these merely enjoy powers lent by the centre, which can take them back at any time. Brexit was thus presented as a project to 'take back control of our money, laws and borders' and re-affirming parliamentary sovereignty. After the 2016 referendum the case moved to popular sovereignty but that does not affect our argument as it was the sovereignty of a putative unitary British people or demos. As Prime Minister Theresa May (2017) put it, 'supranational institutions as strong as those created by the European Union sit very uneasily in relation to our political history and way of life.'

A different view, however, is that the United Kingdom is not a unitary state but a union of nations or union state (Rokkan and Urwin 1983, in which the issue of sovereignty has never definitively been resolved, but kept in abeyance. Since devolution, this longstanding thesis has widened into an argument that the settlement should be regarded as creating new constitutional norms and expectations and principles of consent, beyond the strict letter of the devolution statues (Douglas-Scott, 2019; Himsworth and O'Neill 2015; McCrudden and Halberstam, 2018.

Accordingly, both the European Union and the United Kingdom can be conceptualized as plurinational unions, without fundamental agreement on demos (the people), telos (the ultimate goal), the locus of sovereignty, or geographical scope (Keating, 2021). In this perspective, sovereignty is not as an absolute fact but a set of relationships (Loughlin, 2017; Loughlin and Tierney, 2018) and so may be divided and shared both within the EU and within member states (MacCormick, 1999). These matters are endlessly debated but are never definitively resolved; instead there is a series of institutional compromises while foundational issues are left in abeyance. Foley (2012) has argued that many constitutions work on the basis of 'silences' but the EU and the UK are particularly dependent on them. In this respect, the EU and the UK constitution, far from being incompatible, are a good fit, not because they resolve the sovereignty issue but because they allow it to remain open and continually negotiated. This article will show how the UK devolution settlement was embedded in EU membership, which managed complex issues about sovereignty, borders and competences. Brexit has exposed fault lines and exerted a powerful centrifugal effect within the United Kingdom as its component parts seek their own place within the European architecture, creating new borders and boundaries but without a single coherent or hierarchical territorial order.

\section{Devolution and Europe}

Before 1999, the United Kingdom contained three jurisdictions, England-and-Wales, Scotland and Northern Ireland, with significant variations in law and regulation but all subject to a single Parliament. Devolution added legislatures in Scotland, Wales and Northern Ireland. All competences not expressly reserved to the centre are devolved and there is no hierarchy of laws. Westminster does reserve the

Thanks to the referees of this article and to the European Commission Horizon 2020 project Integrating Diversity in the European Union, 822304. 
power to legislate in devolved fields but subject to the Sewel Convention, that it will not 'normally' do so. This was untested in law before the Brexit referendum. Northern Ireland has a consociational form of government based on power-sharing between the nationalist and unionist communities

The settlement reserves foreign affairs, including relations with the European Union, to the centre. The Northern Ireland settlement has a transnational dimension. Citizens in Northern Ireland are invited to define themselves as British, Irish or any combination of these. People born in Northern Ireland to parents legally resident there have a right to Irish, and thus European, citizenship. East-west bodies link the UK and Ireland and north-south bodies connect the two parts of Ireland. A British-Irish Council brings the British and Irish governments together with those in Scotland, Wales, Northern Ireland, the Isle of Man and the Channel Islands. The Good Friday Agreement (GFA) provided that, for the first time since partition in 1922, the border between the two parts of Ireland is recognized by both states. There is a provision that Ireland can unify if approved by referendum in both parts. ross-border cooperation was encouraged as well as all-Ireland institutions for matters like tourism promotion and energy.

Like the UK itself, the nature of the devolution settlement is contested. It might be seen as an adaptation of the unitary state, an emerging federation or a new iteration of the union of self-determining nations (Casañas Adam, 2017; Tierney, 2018). It is this very ambivalence and lack of agreed telos that explains its broad acceptance. Although significant political forces favour the independence of Scotland and the reunification of Northern Ireland with the rest of Ireland, these were contained before 2016 within the wider European framework.

European ideas about divided and shared sovereignty helped underpin similar arguments about the United Kingdom as a 'post-sovereign' polity (MacCormick, 1999; Keating, 2001). This has opened opportunities for 'third-way' ideas about the national question, between independence and union, even though the EU itself has made little constitutional provision for such cases. As early as 1973, there were hopes that common membership of the European Communities of Ireland and the UK would open new approaches to the otherwise zero-sum national question (Dorr, 2017). In Scotland, EU membership partially defused the national question, as the Scottish National Party (SNP) adopted a policy of independence in Europe, so that independence would not close the border. In the independence referendum campaign of 2014, they argued that Scotland might leave the political union with the UK but would stay in the European union, as well as the monetary, monarchical, defence and social unions (Keating and McEwen, 2017) so lowering the stakes. The anti-independence forces were reduced to arguing that Scotland might be excluded from the European Union.

The devolution statutes provided that the devolved governments and legislatures were bound by EU law, allowing any court to strike down any devolved legislation contravening it. Within the scope of EU law and regulation, however, the devolved nations had the same degree of discretion in transposing directives and applying policies as do Member State governments. So, in most devolved fields, there was no UK level of regulation and no UK-wide departments.

While that macro-economic stabilization is reserved to the centre, there is no provision (except a vague sentence in the Northern Ireland Act) for an integrated market. This was provided, instead, by the European regulation and, particularly, the EU Internal Market ${ }^{1}$ regime. Since the devolved bodies have wide regulatory competences, notably in environment, food standards and agriculture, it was the EU framework that avoided internal regulatory borders.

It is also Europe that assures common human rights across the United Kingdom. The European Convention for the Protection of Human Rights and Fundamental Freedoms (of the Council of Europe) was embodied into the devolution settlement and judgements of the European Court of Human Rights (ECHR) are binding in Scotland, Wales and Northern Ireland in respect of devolved matters. For

1 In the debate, references are made variously to 'internal' and 'single' market. For clarity, we standardize on the former. 
reserved matters (and everything in England), judgements of the Court can be transposed into law by Parliament, using a fast-track mechanism, so preserving UK sovereignty. The Charter of Rights of the European Union provided further protection, in spite of UK efforts to opt out. Eurosceptics have long argued that this gives 'foreign judges' influence over British citizens and wish to repeal the Human Rights Act. There is a movement for a British Bill of Rights, as a supplement or (for Eurosceptics) replacement for the ECHR and as a statement of unity. As the House of Lords and House of Commons Joint Committee on Human Rights (2008: 96) out it: 'there is an inevitable and entirely appropriate link with national identity. A national bill of rights is an expression of national identity and the process of drawing one up deliberately invites reflection on what it is that "binds us together as a nation," what we regard as of fundamental importance, and which values we consider to guide us. It is potentially a moment of national definition.' This poses the very question that the devolution settlement managed to avoid. In Scotland, a quarter of the citizenry do not feel at all British. In Northern Ireland, a key principle of the Good Friday Agreement is to extend rights to all citizens, recognizing the legitimacy of a nonBritish identity. The European rights regimes, which detach rights from contested ideas of nationality, have proved acceptable in the devolved territories. Most challenges to devolved competences have been made under EU or ECHR rather than domestic law.

Europe also provided a common regime of freedom of movement in the face of differing attitudes across the nations. After 2004, successive UK governments sought to restrict access of EU migrants; this was a key part of David Cameron's attempted renegotiation. The Leave vote in England was attributed by many Conservative and Labour MPs to migration concerns, including the presence of EU workers. The issue has been framed differently in Scotland, where there is a cross-party consensus that Scotland needs immigrants for demographic and economic reasons. The Welsh Government also takes a liberal line on freedom of movement and Northern Ireland ministers have expressed support for movement of key workers.

A legally ill-specified uncodified Common Travel Area (Connelly, 2018) between Ireland and the United Kingdom provided for free movement including rights to work after Irish independence in 1922 and withdrawal from the Commonwealth in 1949, although this open border meant that Ireland was unable to join the Schengen zone. Simultaneous UK and Irish membership from 1972 brought free trade. A combination of the GFA and the European Internal Market later allowed a further opening of the frontier and the abolition of any physical border. While the internal power-sharing arrangements that forms the other main component of the GFA has had a chequered history, the opening of the border was a success. Indeed, by 2016 the border had largely ceased to be an object of contention. Surveys since 2009 had shown that there was no longer a plurality for Irish unification among Catholic voters; the most favoured option was power-sharing under the Good Friday Agreement (Northern Ireland Life and Times Survey). ${ }^{2}$ Political parties in the Republic of Ireland held to reunification as an ideal, but, with the exception of Sinn Féin, neither they nor the general public showed much enthusiasm for realizing it.

Common EU membership also transformed relations between the United Kingdom and the Republic of Ireland. In the referendum of 1973, Irish accession was supported by 83 per cent.While there have been nationalist objections to further integration, represented in referendum campaigns, the prevailing view is that membership has enhanced Ireland's effective sovereignty by reducing dependence on the UK and being part of a powerful supranational organization. At the political level, the UK and Ireland came closer as ministers met on equal terms at European meetings and, from the 1980s, cooperated in addressing the Northern Ireland question (Coakley and Todd, 2020).

2 By 2013 this also commanded plurality support among those identifying as Irish. 


\section{Brexit Means Brexit}

The UK Government's response to the Leave vote in the EU referendum of 2016 was Theresa May's much-mocked 'Brexit means Brexit'. This became an insistence the UK withdraw from the Internal Market and the Customs Union and be free in all respects from the jurisdiction of the Court of Justice of the European Union (May, 2017). That ruled out compromises such as the European Economic Area (EEA), or the Swiss option. Some radical pro-Brexit politicians favoured having no special agreement with the EU at all but trading on WTO terms. Prime Minister Theresa May refused to rule this out when she insisted that a bad deal was worse than no deal. The agreement negotiated by May in 2018, however, was accompanied by a Political Declaration pledging 'an ambitious, broad, deep and flexible partnership' (Department for Exiting the European Union, 2018). This was repeated in the final version of the agreement negotiated by Boris Johnson in 2019. Following the General Election of December 2019, however, papers showed the UK (Johnson, 2020) and the EU (European Commission, 2020) to be far apart, with the former insisting on regulatory sovereignty and the latter seeking extensive assurances about a level playing field as well as an institutionalized overarching agreement.

The response in the devolved territories was very different. The nationalist parties in Scotland (Scottish National Party), Wales (Plaid Cymru) and Northern Ireland (Sinn Féin and Social Democratic and Labour Party) all supported Remain. This represented a shift on the part of Sinn Féin which had opposed every EU referendum in Ireland on sovereignty (and left-wing) grounds but which now argued that Brexit would 'repartition Ireland' by closing the border. The other nationalist parties had long concluded that the EU represented an external support system for small nations and a guarantee of access to the wider market. The Labour-controlled Welsh Government was also pro-Remain. The largest unionist party in Northern Ireland, the Democratic Unionist Party, supported Leave, in line with its historic Euroscepticism, while the more moderate Ulster Unionist Party supported Remain, at least until the referendum.

The referendum outcome was also territorially differentiated. England and Wales both voted Leave by 53 per cent. Scotland voted 62 per cent for Remain. Northern Ireland voted 56 per cent Remain but there was a marked community division. Nationalists voted by almost 90 per cent Remain but unionists voted by two thirds to Leave (Garry, 2017). The referendum result thus heightened political divisions over borders within the United Kingdom but without a definitive outcome.

The main concern of the EU, meanwhile, was to ensure that any deal did not compromise the integrity of its Internal market, while damaging trading links with the UK as little as possible (Randerson, 2018). It was also pledged to avoid anything that could harm the Northern Ireland settlement by reintroducing a hard border between the two parts of Ireland. This was made one of the three conditions for starting negotiations on the future relationship, along with citizen rights and the financial settlement.

The other key actor was the Republic of Ireland. ${ }^{3}$ Because of the size of trade flows this is the EU country most affected by Brexit. It is also a recognized partner in the Northern Ireland settlement. Immediately after the referendum, some actors (especially in the UK) thought that it might privilege its links with the UK and seek a bilateral deal. A small but vocal sector even promoted Ireland's withdrawal from the EU so that it could position itself with the UK orbit. It soon became clear, however, that Ireland had chosen to align itself with the other 26 member states and to use their position as a loyal European player to secure their goal of keeping an open border between the two parts of the island (Connelly, 2018).

An early test of the rules under which the issue would be played out was provided in a challenge mounted by the Scottish and Welsh governments, later joined at the Supreme Court by suits arising in Northern Ireland. The principal issue at stake was the claim led by Gina Miller that the approval of Parliament was required before the UK Government could trigger Article 50 to start the process of EU

3 The official name of the state is now 'Ireland' but this helps avoid confusion with the island as a whole. 
withdrawal. The devolution issue was whether, under the Sewel Convention, there needed to be a legislative consent process, given that devolved competences were at stake. The ruling of the UK Supreme Court (2017) represented the most centralizing interpretation of the devolution settlement. It stated that, as Sewel was a mere 'political' convention, it had no force in law. This effectively undermined the political standing of the devolved governments in the Brexit process.

These conflicting tendencies within and between governments ensured that there was no coherent response to the referendum result. Instead, there were three scenarios attempted simultaneously: disintegration as Scotland and Northern Ireland left the United Kingdom in order to remain in the EU; recentralization as the UK was reconstituted as a unitary state outside the EU; reconfiguration as the smaller nations sought to remain within the EU Internal market and policy frames while not leaving the United Kingdom.

\section{Disintegration}

Immediately after the referendum, Scottish and Irish nationalists challenged the legitimacy of the UK mandate to leave. Scotland's First Minister called for another independence referendum on the grounds that Brexit constituted the 'material change of circumstances' which they had earlier said would justify one. ${ }^{4}$ Sinn Féin called for a border poll on reunification as permitted under the Good Friday Agreement. These gambits did not succeed because of a lack of electoral support and because both would keep open the European borders but close those with the rest of the UK.

The policy of the Scottish National Party (SNP) since the mid-1980s has been to seek independence from the UK but remain within the EU. This combination, however, did not always convince voters. While Scotland has long been more pro-European than England, nationalist voters have been no more pro-European than the rest (McCrone, 2006). There was little correlation between voting in the independence referendum of 2014 and the EU referendum of 2016; some 30 per cent of independence voters from 2014 voted for Brexit in 2016 (Prosser and Fieldhouse, 2017). So there was no initial postBrexit 'bounce' in support for independence, which remained where it had been in 2014, at around 40 per cent. In the snap general election of 2017, the SNP, while retaining a majority of Scottish MPs, lost support. By the time Brexit occurred in January 2020, the situation had evolved. As the Scottish Conservatives (formerly pro-Remain) changed tack to support Brexit and an all-UK withdrawal, the SNP doubled down on independence and remaining in Europe. This lost the nationalists much of their pro-Leave support but won over Remainers, producing a polarization between a pro-independence/ proEurope SNP and a hard unionist/ pro-Brexit Conservative Party (McCrone and Keating, 2021). The SNP won battle with 45 per cent of the vote, with the Conservatives coming second at 25 per cent. By 2020 , a series of polls showed a majority for independence and an alignment of pro-European and proindependence positions (Diffley, 2020; What Scotland Thinks, 2020).

The second difficulty was that, if Scotland were independent in the EU but England and Wales were outside, there would be a hard EU border between them, undermining the independence offering of 2014, which would have left all borders open. Scotland does around four times as much trade with the rest of the UK than it does with the EU. This meant that the harder the new border between the EU and the UK created by Brexit, the greater the grievance in Scotland, but the more difficult independence became. The EU-UK trade deal thus makes Scottish independence rather easier.

In Northern Ireland, the Brexit vote drove a wedge between the unionist and nationalist parties and undermined the power-sharing institutions, which were already in trouble and collapsed between early 2017 and early 2020. Sinn Féin's call for a border poll received almost no support from other parties in either part of Ireland, as they saw it as destabilizing and a threat to the internal settlement. Yet the

4 This was in their manifesto for the 2016 Scottish elections in which pro-independence parties (SNP and Greens) gained a majority. 
political mood did change. By 2017, Irish unification was again the first preference of a plurality of Catholics and those identifying as Irish; in 2019 it was just short of a majority among those groups (Northern Ireland Life and Times Survey). ${ }^{5}$ The matter started to be discussed in official circles in Dublin ${ }^{6}$ where the consensus was that, at some point, reunification might become politically inescapable, but that this could not take the form of a unitary and territorially bounded nation-state based on the Republic. There would have to be some territorial differentiation and guarantees for the unionists in the north, including their links with Great Britain.

The most surprising challenge came not from the periphery but from within England. Support for Brexit there is related not to British but to English identity (Ashcroft, 2019; Future of England, 2019). Surveys have even shown that a majority of pro-Brexit voters in England believe that the secession of both Northern Ireland and Scotland would be a price worth paying to achieve Brexit (Ashcroft, 2019; Future of England, 2019). This would leave a sovereign bordered English state, free of all federal elements, consistent with English assumptions about the constitution.

The European Union does not officially pronounce on secessionist challenges within member states but few in Brussels look on them with favour and countries facing such challenges tend to support each other. At the time of the Scottish independence referendum in 2014, José Manuel Barroso, Commission President, even said that an independent Scotland might never be allowed into the EU. After the EU referendum, European opinion softened but there was no encouragement of Scottish independence. Ireland was another matter and the Council of the EU made it clear that a united Ireland would be regarded as a continuing Member State, following the precedent of Germany (European Parliament, 2017).

\section{Recentralization}

Withdrawal from the EU would remove the only UK-wide policy frameworks in a number of fields, including environment, agricultural and food standards regulation and subsidies for agriculture and business. That raised the prospect of new regulatory borders within the UK, negative externalities and regulatory arbitrage. It would also complicate negotiation of trade deals with the EU and third countries, who would look for access to a unitary market. There was wide agreement across the various governments that this needed to be addressed but not on how.

The initial UK Government response, in the EU Withdrawal Bill, was that all competences returning from the EU would revert to Westminster regardless of whether they were devolved, with provision to 'release' competences back if centralization proved unnecessary. The argument was that the competences were not really devolved as the territorial administrations were only 'implementing' EU policy and henceforth, they would implement UK policy (UK Government, 2017a,b) This provoked strong opposition and the bill was amended in its last stages so that the competences would remain devolved but the UK Government could take them back by statutory instrument ${ }^{7}$ as it chose. At this point, the Welsh Government and Assembly agreed to consent to the legislation but the Scottish Government and Parliament refused. ${ }^{8}$

The debate then continued on two tracks. One concerned post-Brexit policy 'frameworks' in specific parts of sectors such as agriculture and the environment. Technical and largely depoliticized discussions were held among all four governments, mostly at official level. There was wide agreement on policy substance but not on enforcement mechanisms. The Welsh Government, which wished to use the process

\footnotetext{
Brexit was not the only factor. Support for reunification had been rising from its lowest point since 2014 and there were domestic factors including the absence of functioning devolved institutions between early 2017 and early 2020 .

6 A referee has asked for my source for this statement. I was present at these discussions.

7 That is, without primary legislation.

8 This included all parties except the Conservatives.
} 
to advance its ideas about cooperative federalism, favoured common policies, jointly agreed, while the Scottish Government stressed policy autonomy. The Welsh Government also signed an agreement with the UK Government on cooperation and joint working (Cabinet Office, 2018). As the Northern Ireland Executive was out of action between early 2017 and early 2020, Northern Ireland civil servants participated in the discussions.

The second track was more politicized and contentious. This concerned the broader concept of the 'UK internal market' which, by analogy with the EU market, extends to matters that might not be covered by the sectoral frameworks. The European Internal market harmonizes (or provides for mutual recognition of) product standards, public procurement, professional qualifications and other matters. Going beyond the old 'conferral' principle whereby the EU was give specific powers, it operates transversally across fields in a way that can be expanded over time (Weatherill, 2017). This can be politically contentious as there is no clear consensus on where the market should prevail and where it should be curtailed by social or environmental considerations. Nor is there consensus on the territorial level at which these principles should be applied. As a living, transversal principle, the Internal Market can intrude in unexpected ways. Scottish legislation on minimum pricing of alcohol was passed as a public health matter but was challenged by producers as an interference in the market and restraint on competition. It took a series of appeals from the Scottish courts up to the Court of Justice of the EU and back via the UK Supreme Court to resolve that this was a justifiable restraint on market activity.

The EU has an institutional mechanism to manage the Internal market. Measures are brought forward by the European Commission and adopted by the Council of the European Union and the European Parliament. They are implemented either by laws directly applicable across the Union or transposed into national law by member states (or sub-state governments where appropriate). The process is governed by the principles of subsidiarity and proportionality. Infringement is dealt with by national courts and, ultimately, the Court of Justice of the European Union. There are provisions for mutual recognition.

There is no equivalent single/ internal market provision in the UK devolution legislation, apart from a rather vague reference in the Northern Ireland Act. Instead, reserved competences are set out clearly, with everything else devolved. It is EU law that secures the UK internal market. Nor is there anything in the UK devolution settlement corresponding to the elaborate, multilevel process for making single/ internal market rules in the EU. There is no neutral body like the Commission to make proposals and monitor compliance. UK courts do not have the same role and expertise as the Court of Justice of the EU in enforcing market rules. There are no principles of subsidiarity and proportionality.

From March 2019, the Scottish Government refused to participate in discussions about the Internal Market. The Welsh Government and Northern Ireland civil servants did participate but, after the General Election of late 2019, the re-elected Conservative Government then proceeded unilaterally, producing a White Paper (in which the UK was described as a 'unitary state') and a Bill in 2020 (Department of Business, Energy and Industrial Strategy, 2020a,b). The UK Internal Market Act gives ministers sweeping powers to enforce mutual recognition and non-discrimination across the four jurisdictions. Existing differences and some social and health matters are exempted but these are much less extensive than the exemptions permitted under the EU Internal Market provisions. Only after an amendment in the House or Lords, the Bill was amended to provide a weak and non-binding consent mechanism for amendments (equivalent to the Sewel Convention) to the list of exemptions.The result is that, while the devolved governments retain regulatory competences, these are undermined by the fact that goods and services originating in, or imported into, England can be marketed anywhere. There are none of the counterparts, including subsidiarity and proportionality found in the EU Internal Market and nothing corresponding to the Council of the EU or the European Commission. 


\section{Differentiated Brexit}

Given the differing votes and political demands across the UK, demands have arisen for an asymmetrical or differentiated Brexit, allowing some parts of the UK to remain closer to the EU than others. This might be seen as a counterpart to the idea of 'external differentiation' in the EU, whereby non-member states participate in some of its programmes (Schimmelfennig and Winzen, 2020). The idea was touted or a 'reverse Greenland', referring to the way that regions within Member States have a differentiated relationship. The Dalriada ${ }^{9}$ proposal (O'Leary, 2016) envisaged that England and Wales could leave the EU, with Scotland and Northern Ireland retaining the UK's membership.

The SNP-controlled Scottish Government's first preference was independence within the EU; its second was that the whole UK remain in the Internal Market and Customs Union. Failing those it proposed a differentiated Brexit (Scottish Government, 2016). Scotland would remain in the Internal Market for goods and services as part of the European Economic Area. If the UK were to leave the EU customs union, Scotland would also leave, remaining in a customs union with the UK. There would be free movement of workers between Scotland and the EU-27 and Scotland would participate in European social provisions, academic exchange and research and in aspects of EU Justice and Home Affairs policies.

These proposals raised serious challenges. While the aim was to keep open access to both EU and UK markets, there would inevitably be new borders and barriers. With Scotland within the UK customs union, there could controls (and possibly tariffs) on trade with the EU. If the UK and EU were to diverge over regulations on goods and services, then Scotland could face restrictions of trade with England and Wales. Free movement of workers between Scotland and the EU would be easier to manage and could be monitored at the place of work rather than at the border. Allowing Scottish workers reciprocal rights in other EEA states, however, would require provisions to define a Scottish worker. Perhaps the biggest difficulty in the proposals was that, for Scotland to remain compliant with Internal Market regulations, the Scottish Parliament and Government would require new competences that are currently reserved to Westminster. In that case, it might be argued, independence would be an easier solution.

In the event, the UK Government refused to discuss the proposals, which meant that they never faced the test of acceptability to Europe. Both the Scottish and Welsh Governments then brought forward 'continuity bills' to allow them to maintain 'dynamic alignment' with EU regulations in devolved areas and the EU Charter of Rights. Following their agreement with the UK Government, the Welsh Government withdrew their continuity bill but in 2020 the Scottish Government produced a new one (enacted in 2020). This allow ministers to align dynamically with EU regulations but that, in turn, could mean diverging from the UK and clash with frameworks and UK internal market rules.

Northern Ireland, on the other hand, was not a purely internal question but one in which the Government of Ireland had an interest both as a Member State and as guarantor of the Good Friday Agreement. The EU declared an interest, given the importance of the European framework to the peace settlement, the guarantees of rights in the Good Friday Agreement, functional integration across the Irish border and investments in cross-border programmes (European Commission, 2017). Yet it was also concerned that an open border between Ireland and the United Kingdom could breach the integrity of the Internal Market. The UK Government was hampered after the losing its majority in the General Election of 2017 when it made a deal for Parliamentary support with the Democratic Unionist Party (DUP). The DUP exists to maintain the border in Ireland by keeping Northern Ireland within the United Kingdom, is historically Eurosceptic and campaigned for Brexit. On the other hand, it had eventually accepted the Good Friday Agreement with the open border and cross-border bodies that went with it. ${ }^{10}$

9 Dalriada (Dalriata) was an ancient kingdom spanning what is now the west of Scotland and the north of Ireland.

10 The DUP had opposed the GFA and was not fully signed up until the St Andrews Agreement of 2006. 
All sides - the UK Government, Irish Government, EU, and both nationalist and unionist parties in Northern Ireland - agreed that Brexit should not lead to new, hard border between Northern Ireland and the Republic of Ireland or threaten the Good Friday Agreement. Yet there was deep disagreement over what this meant. The UK Government had a narrow interpretation of the GFA, which actually says rather little about Europe. Focusing on the transactional aspect of the border, it agreed that there should be no physical infrastructure at the frontier itself. Eventually, it hoped that the issue could be managed by technology and by putting any inspection points a few kilometres from the border. Tariffs could be eliminated in a future trade deal and there need only be as much regulatory alignment as required by a strict interpretation of the GFA. The Irish perspective was much larger and included not just the text of the GFA but all the subsequent gains that opening the border had made possible (which might be described in European terminology as the border acquis). From this point of view, a virtual border was still a border and inspection points away from the frontier are still obstacles to free movement. In a still broader perspective, the open border allowed for the territorial projection of the imagined communities of both nationalists and unionists so that any hardening of it would be seen as a threat to nationalists. The border is also a daily presence in border communities, shaping relationships across the national divide in complex ways (Todd, 2018; Hayward, 2017, 2018).

An alternative to a hard border between the two parts of Ireland would be to keep Northern Ireland within the Customs Union and/ or the Internal Market. This, however, would mean an economic and regulatory border 'in the Irish Sea' between Northern Ireland and Great Britain ${ }^{11}$. Unionists opposed this because Northern Ireland does more trade with Great Britain than with the rest of Ireland, but principally because it would represent a breach of their imagined national community, which is the UK as a whole.

Some pro-Brexit politicians even insisted that they would not put up a border in Ireland at all; any border would be the fault of the Europeans and the Irish (Redwood, 2017). Apart from being a contradiction for a movement that had campaigned to take back control of borders, it was not acceptable to the EU, with its concern for the integrity of its Internal Market and insistence that Northern Ireland should not be an open frontier for unregulated imports and exports. The EU side, however, made the same mistake as the UK Government, when it downplayed the implications of a border in the Irish Sea, suggesting that it could be handled by technology. ${ }^{12}$

There is no solution to this conundrum that would satisfy all parties. The issue was not where the border between the UK and the EU in Ireland should go but what sort of border it should be. The withdrawal agreement of 2018 included a Northern Ireland protocol, which expressed the hope that the future overall agreement between the EU and the UK would avoid the need for a hard border in Ireland; this would imply a very soft Brexit. If that failed, any customs formalities and regulatory controls would be done electronically, without any physical infrastructure at the border. Yet such a virtual border would still be a border as long as there are regulatory differences between the EU and the UK. Failing these two options, there would be regulatory alignment between the two parts of Ireland as far as necessary in order to keep the Good Friday Agreement working. This 'Irish Backstop' was ambiguous as the UK and Irish governments still had very different interpretations of its scope (Connelly, 2018). Although the UK Government had been obliged to modify earlier proposals during an EU summit in December 2017 because of objections from the DUP ${ }^{13}$, this still did not satisfy unionists that there would be no border in the Irish Sea. The matter of customs was dealt with in the 2018 withdrawal agreement in the provision that the whole of the UK would remain in a 'single customs territory' with the EU.

11 Great Britain refers to the island comprising England, Scotland and Wales. The United Kingdom includes Great Britain and Northern Ireland.

12 Michel Barnier (2019) said: 'We will obviously need to clarify how and where this control will be done. But ultimately, these are only technical controls on goods. No more, no less.'

13 On which the Conservative Party relied for their parliamentary majority after the General Election of 2017. 
Finally, after the Conservatives had gained a majority in the General Election of 2019, they abandoned the DUP and carved out a highly differentiated status for Northern Ireland. Northern Ireland alone would have customs-free access to the EU while also being in the UK customs union. Goods passing from Great Britain through Northern Ireland to the EU would pay applicable customs duties. Northern Ireland would remain in general regulatory alignment with the EU for goods. So there would be a border in the Irish Sea as well as the (open) border between the two parts of Ireland. Not surprisingly, the DUP refused to support the deal. UK Prime Minister Boris Johnson initially declared that there would be no checks at the border (ITV, 2019); EU negotiator Michel Barnier insisted that there would (Guardian, 27-01-2020). Johnson later admitted that there would (Colston, 2020). The outcome bears a resemblance to the Scottish Government proposals rejected in 2017 as incompatible with the UK union. Matters were further confused when the UK Government included in its Internal Market Bill a clause allowing it to derogate from the Agreement in the application of state aid rules and regulatory requirements for trade in respect of Northern Ireland; this was later withdrawn after domestic and European objections.

\section{Conclusion}

The United Kingdom has presented a model of territorial/ national accommodation which, rather than seeking a 'solution' to the nationalities question, provided a basis for negotiation and adjustment. This rests upon historic understandings of the state as a union, together with the overarching European framework. Nation, state and sovereignty were all contested but this rarely became a zero-sum game; even the prospect of Scottish independence in 2014 was attenuated by the fact that both successor states would remain within the EU. This contrasts with Spain, where the Catalan crisis has posed incommensurate visions of nation and sovereignty. It shares more in common with Belgium, where the national question is continually negotiated and adjusted within a more flexible state and the wider European order - although in other respects the Belgian model is distinct. Brexit, however, represents an assertion of a territorially-bounded and internally-integrated state which, arguably, the United Kingdom never was.

The EU has never been an actor in the UK constitutional reform or the territorial fall-out from Brexit, except in the case of the Irish border, where it had a stake in protecting its own economic border and in supporting a loyal Member State. Similarly, it has stayed out of territorial conflicts in Spain and elsewhere, insisting that these are internal matters. In a wider sense, however, the European context provides an important framework for state rescaling and territorial management (Keating 2013).

Another lesson from the case concerns differentiated integration (Schimmelfennig and Winzen 2020). The EU has permitted Member States to opt out of some aspects of integration and non-Member States to opt in. It has allowed regions of some Member States to opt out, wholly or entirely (Faroes, Greenland, Canaries, Azores). The Brexit agreement, with its provisions for Northern Ireland, is the first instance of a region of non-Member State having a significant opt-in. It seems, however, that this stems from the specific circumstances of the province; no such consideration was given to Scotland. It remains true that, while European integration has major effects on rescaling within Member States and beyond and has intervened in spatial planning and development, it has not itself assumed a political role in managing territorial relations and conflicts (McGarry and Keating, 2006). Brexit has increased centrifugal tendencies within the United Kingdom but they remain a matter for a domestic political arena now dominated by unitarist and centralizing tendencies. 


\section{References}

Ashcroft, Lord (2019), England and the Union https://lordashcroftpolls.com/2019/10/england-and-theunion/

Cabinet Office (2018), Intergovernmental Agreement on the European Union (Withdrawal) Bill and the Establishment of Common Frameworks, London: UK Government.

Casañas Adam, E. (2017, 'An unanswered or unanswerable question? The Scottish Parliament's competence to legislate for an Independence Referendum for Scotland', Revista Catalana de Dret Públic, 54: 81-99.

Coakley, J. and Todd, J. (2020), Negotiating a Settlement in Northern Ireland, 1969-2019, Oxford: Oxford University Press.

Colston, T. (2020), 'Boris Johnson promised frictionless trade after Brexit but now his government admits new border checks are 'inevitable', Business Insider, 11-02-20, https://www.businessinsider.com/boris-johnson-michael-gove-admits-brexit-border-checks-areinevitable-2020-2?r=US\&IR=T

Connelly, T. (2018), Brexit and Ireland: The Dangers, the Opportunities, and the Inside Story of the Irish Response, London: Penguin.

Department for Exiting the European Union (2018), Withdrawal Agreement and Political Declaration on the future relationship between the $U K$ and the $E U$, https://www.gov.uk/government/publications/withdrawal-agreement-and-political-declaration

Department of Business, Energy and Industrial Strategy (2020a), UK Internal Market, CP 278, London: UK Government.

Department of Business, Energy and Industrial Strategy (2020b), Internal Market Bill, 2020: Policy Statements, https://www.gov.uk/government/publications/uk-internal-market-bill-2020-policystatements

Dicey, A.V. (1959), Introduction to the Study of the Law of the Constitution, Basingstoke: Macmillan.

Diffley M. (2020), 'Tory Revival in Scotland? Recent Evidence, Future Prospects', in David Torrance (ed.), Ruth Davidson's Conservatives, Edinburgh: Edinburgh University Press, 31-41.

Dorr, N. (2017), The Search for Peace in Northern Ireland. Sunningdale, Dublin: Royal Irish Academy.

Douglas-Scott, S. (2019), 'The Constitutional Implications of the EU (Withdrawal) Act 2018: A Critical Appraisal', Queen Mary School of Law Legal Studies Research Paper No. 299/2019. Available at SSRN: https://ssrn.com/abstract=3316710

European Commission (2017), Guiding principles for the Dialogue on Ireland/Northern Ireland, TF50 (2017); Brussels: European Commission.

European Commission (2020), Draft Text of the Agreement on the New Partnership with the United Kingdom, UKTF (2020) https://ec.europa.eu/info/sites/info/files/200318-draft-agreement-gen.pdf

European Parliament (2017), At a Glance. Post-European Council Briefing, https://www.europarl.europa.eu/RegData/etudes/ATAG/2017/603226/EPRS_ATA(2017)603226_E N.pdf.

Foley, M. (2012), The Silence of Constitutions. Gaps, 'abeyances' and political temperament in the maintenance of government, London: Routledge Revivals.

$\begin{array}{cccc}\text { Future } & \text { of } & \text { England } & \text { Survey }\end{array}$ (2019), 
Garry J. (2017), The EU referendum Vote in Northern Ireland: Implications for our understanding of citizens' political views and behaviour https://www.qub.ac.uk/brexit/Brexitfilestore/Filetoupload,728121,en.pdf

Grob- Fitzgibbon, B. (2016), Continental Drift. Britain and Europe from the End of Empire to the Rise of Euroscepticism, Cambridge: Cambridge University Press.

Hayward, K. (2017), Bordering on Brexit. Views from Local Communities in the Central Border Region of Ireland / Northern Ireland, Belfast: Centre for International Borders Research, Queen's University.

Hayward, K. (2018), 'The pivotal position of the Irish border in the UK's withdrawal from the European Union', Space and Polity, 22.2: 238-54.

Himsworth, Chris and Christine O'Neill (2015), Scotland's Constitution: Law and Practice, 3rd Edition, Hayward's Heath: Bloomsbury.

ITV (2019), 'Boris Johnson insists there will be no border checks post-Brexit and labels leaked Treasury document "wrong", 08-12-19, https://www.itv.com/news/2019-12-08/boris-johnson-insists-nobrexit-checks-between-northern-ireland-great-britain-labels-leaked-treasury-document-wrong/

Johnson, B. (2020), UK / EU relations: Written statement - HCWS86, https://www.parliament.uk/business/publications/written-questions-answers-statements/writtenstatement/Commons/2020-02-03/HCWS86/

Keating, M. (2001), Plurinational Democracy. Stateless Nations in a Post-Sovereignty Era, Oxford: Oxford University Press.

Keating, M. (2013), Rescaling the European State. The making of territory and the rise of the meso, Oxford: Oxford University Press.

Keating, M. (2021), State and Nation in the United Kingdom: The Fractured Union, Oxford: Oxford University Press.

Keating, M. and McEwen, N. (2017), 'The Scottish Independence Debate', in Michael Keating (ed.), Debating Scotland: Issues of Independence and Union in the 2014 Referendum, Oxford University Press, 1-26.

Loughlin, M. (2017), The Political Constitution Revisited, LSE Law, Society and Economy Working Papers 18/2017 London School of Economics and Political Science Law Department.

MacCormick, N. (1999), Questioning Sovereignty. Law, State and Nation in the European Commonwealth, Oxford: Oxford University Press.

May, T. (2017), Plan for Britain. The Prime Minister's speech on Brexit, London: Prime Minister's Office, https://www.gov.uk/government/speeches/the-governments-negotiating-objectives-forexiting-the-eu-pm-speech

McCrone, D. (2006), 'Scotland and Europe: Examining the Myths', talk given to the $6^{\text {th }}$ annual conference of the Hansard Society Scotland, Edinburgh: Institute of Governance.

McCrone, D. and Keating, M. (2021), 'Questions of Sovereignty: Redefining Politics in Scotland?', The Political Quarterly, 92.1: 1-15.

McCrudden, C. and Halberstam. D. (2018), 'Miller and Northern Ireland: A Critical Constitutional Response', The UK Supreme Court Yearbook, 8, 299-343.

McGarry, J. and Keating, M. 'Introduction: European Integration and the Nationalities Question', in John McGarry and Michael Keating (eds.), European Integration and the Nationalities Question, Abingdon: Routledge, 1-20. 
McLean I. (2020), 'Understanding the Union' in Michael Keating (ed.), The Oxford Handbook of Scottish Politics, Oxford: Oxford University Press, 118-36.

O'Leary, B. (2016), The Dalriata Document. Towards a Multinational Compromise that Respects Diversity in the United Kingdom, Belfast: Queen's University. https://www.qub.ac.uk/Research/GRI/mitchell-institute/FileStore/Filetoupload,756968,en.pdf

Prosser, C. and Fieldhouse, E. (2017), A tale of two referendums - the 2017 election in Scotland, British Election Study, http://www.britishelectionstudy.com/bes-findings/a-tale-of-two-referendums-the2017-election-in-scotland/\#.WeoCaDb9O7M

Randerson, J. ( 2018), EU won't break the single market for Brexit UK https://www.politico.eu/article/michel-barnier-brexit-customs-eu-wont-break-the-single-marketfor-brexit-uk/

Redwood, J. (2017), The EU now threatens the Republic of Ireland with a hard border, https://johnredwoodsdiary.com/2017/11/10/the-eu-now-threatens-the-republic-of-ireland-with-ahard-border/

Rokkan, S. and Urwin, U. (1983), Economy, Territory, Identity. Politics of West European Peripheries, London: Sage.

Schimmelfennig, F. and Winzen, T. (2020), Ever Looser Union? Differentiated European Integration, Oxford: Oxford University Press.

Scottish Government (2016), Scotland's Place in Europe, Edinburgh: Scottish Government.

Tierney, S. (2018), 'Drifting Towards Federalism? Appraising the Constitution in Light of the Scotland Act 2016 and Wales Act 2017', in Robert Schütze and Stephen Tierney (eds), The United Kingdom and the Federal Idea, Oxford: Hart, 101-22.

Todd, J. (2018), Identity Change after Conflict. Ethnicity, Boundaries and Belonging in the Two Irelands, London: Palgrave.

UK Government (2017a), The United Kingdom's exit from and new partnership with the European Union, London: UK Government.

UK Government (2017b), Legislating for the United Kingdom's withdrawal from the European Union.

UK Supreme Court (2017), Judgment R (on the application of Miller and another) (Respondents) vs. Secretary of State for Exiting the European Union (Appellant), USC 5 (2017).

UK Supreme Court (2018), Judgment. The European Union (Legal Continuity) Scotland Bill, UKSC 64 (2018).

Weatherill, S. (2017), The Internal Market as Legal Concept, Oxford: Oxford University Press.

What Scotland Thinks (2020), 'How would you vote in a Scottish independence referendum if held now?' https://whatscotlandthinks.org/questions/how-would-you-vote-in-the-in-a-scottishindependence-referendum-if-held-now-ask/ 


\section{Author contacts:}

\section{Michael Keating}

Professor of Politics

University of Aberdeen

27 Dundas Street

Edinburgh EH3 6QQ

Email: m.keating@abdn.ac.uk 
With the support of the The European Commission supports the EUI through the European Union budget. This Erasmus+ Programme publication reflects the views only of the author(s), and the Commission cannot be held of the European Union responsible for any use which may be made of the information contained therein. 